\title{
Research on the Current Situation of County Economic Development in Jilin Province
}

\author{
Gao Yuan ${ }^{1, a, ~}{ }^{,}$, Cao Yue ${ }^{2, b}$ \\ Changchun University of Technology, CHINA \\ a407222789@qq.com, b3092484735@qq.com \\ *Gao Yuan
}

Key words: Jilin Province, County Economy, Development.

\begin{abstract}
County economy has an irreplaceable role in the process of China's economic development. Under the urbanization construction with the new construction as the main body, the development of county economy has become an important part of promoting the new urbanization. By combing the county in Jilin Province, summarizing the development of county economy in Jilin Province in the problems and solutions, hoping Jilin county economy healthy, harmonious, stable and rapid development, and making greater achievements.
\end{abstract}

\section{General Trend of County Economic Development in Jilin Province}

The county economy of Jilin Province has made great progress since the 13th Five-Year Plan. In 2018, the GDP of Jilin Province reached 157.472 billion yuan, as shown in Table 1 below. In 2016 and 2018, from the regional economic comparison of Jilin Province, we can see the regional production total. Values and local fiscal revenues have increased, and the proportion of tertiary production has also undergone major changes. The proportion of the primary industry has decreased, and the secondary and tertiary industries have been optimized. At the same time, with the development of urbanization ratio, the per capita disposable income of urban residents and per capita disposable income of peasants continued to increase in 2018. From 2014 to 2018, that is, during the 12th to 13th Five-Year Plan period, the GDP of Jilin Province increased significantly, and maintained a steady growth during the 13th Five-Year Plan period. This shows that Jilin Province in our country is currently growing steadily. The development of county economy is stable and rising gradually.

Table 1. Regional economic comparison between 2016 and 2018

\begin{tabular}{|c|c|c|c|c|}
\hline Categories & Indicators & $\begin{array}{l}\text { Compan } \\
\mathbf{y}\end{array}$ & 2016 & 2018 \\
\hline \multirow{2}{*}{$\begin{array}{l}\text { Economic } \\
\text { development }\end{array}$} & $\begin{array}{l}\text { Gross Regional } \\
\text { Product }\end{array}$ & $\begin{array}{l}\text { Billion } \\
\text { yuan }\end{array}$ & 14274.11 & 15074.62 \\
\hline & Local fiscal revenue & $\begin{array}{l}\text { Billion } \\
\text { yuan }\end{array}$ & 1229.29 & 1240.84 \\
\hline \multirow[t]{2}{*}{$\begin{array}{l}\text { Structural } \\
\text { Adjustment }\end{array}$} & $\begin{array}{l}\text { The Proportion of } \\
\text { Industrial Value } \\
\text { Added to GDP }\end{array}$ & $\%$ & 45.11 & 36.07 \\
\hline & $\begin{array}{l}\text { Three production } \\
\text { proportion }\end{array}$ & l & $11.2: 51.4: 37.4$ & $7.7: 42: 49.8$ \\
\hline \multirow{3}{*}{$\begin{array}{l}\text { People's } \\
\text { livelihood } \\
\text { and } \\
\text { urbanization } \\
\text { rate }\end{array}$} & $\begin{array}{l}\text { People's livelihood } \\
\text { and urbanization } \\
\text { rate }\end{array}$ & $\%$ & 55.31 & 57.53 \\
\hline & $\begin{array}{l}\text { Per capita disposable } \\
\text { income of urban } \\
\text { residents }\end{array}$ & yuan & 24901 & 30172 \\
\hline & $\begin{array}{l}\text { Per capita net income } \\
\text { of farmers }\end{array}$ & yuan & 11326 & 13748 \\
\hline
\end{tabular}

Note: Statistical Data of National Economic and Social Development from the Survey of Jilin Province 


\section{Problems Existing in County Economic Development of Jilin Province}

Although the development of county economy in Jilin Province is stable, there are still many problems in the development of county economy.

\subsection{The unreasonable industrial structure of county}

Because the focus of policy and the allocation of factors are too inclined to big cities, the dual characteristics of industrialization between urban and rural areas in Jilin Province are very distinct. The development of urban industry is the main factor, and the development of county industry is neglected, which makes it difficult for county industry to take advantage of policy guidance. At the same time, the distribution of county industrial structure is uneven. In addition to the distribute of developed counties in Chang Ji Tu region, most counties such as Li Shu County have a single economic structure, with traditional agriculture as the main part and the development of secondary and tertiary industries as the supplement. Most county economies are driven by the primary industry.

\subsection{Lack of necessary financial support for County Economic Development}

In the context of economic recession, county economic financing is more difficult, financing channels are single, and funds are short. This is because the state-owned commercial banks are strict in lending, the credit system of private enterprises in most counties has not yet formed, and it is difficult for county enterprises, especially small and medium-sized enterprises, to get credit support from banks. If they want to develop, they can only rely on their own capital accumulation to circulate, which restricts the further development and growth of County Private enterprises. Although a small number of state-owned enterprises are supported by bank credit, their late start and backward development hinder the further development of county economy in Jilin Province due to the influence of planned economy.

\subsection{Insufficient ability of scientific and technological innovation and lack of technical personnel}

Most of the county-level private enterprises in Jilin Province are small in scale, low in efficiency, low in income and remuneration, and have little room for development, so they can't attract and retain technical talents. In addition, bank loans restrict the development of small and medium-sized enterprises, resulting in weak awareness of independent innovation, low technological level, poor innovation ability and weak international competitiveness of county-level private enterprises in Jilin Province. In addition, scientific research funds in our province mainly flow to cities such as Changchun and Jilin, and the lack of investment in science and technology in most of the remaining country economic development leads to the unbalanced development of county economy. The role is not obvious, the contribution rate of scientific and technological progress to economic development is very low, the scientific and technological reserves are scarce, and the transformation of scientific research results is less, which restricts the economic development of county areas in Jilin Province.

\section{The Countermeasure of County Economic Transition and Development in Jilin Province}

County economic development is an economic and social problem involving structural adjustment, agricultural industrialization, industrialization, urbanization, infrastructure improvement, enterprise restructuring, market environment construction, government function transformation and ideological emancipation.

\subsection{County structural adjustment}

Enhancing the development of traditional industries, introducing modern mechanized technology to improve the core competitiveness of traditional industries; optimizing the three major industrial structures, steadily developing the primary industry, ensuring the development of the secondary industry, focusing on the development of the tertiary industry, and promoting the formation of the county economy in Jilin Province in the proportion of three, two and one industries; at the same time, changing each industry. The development of county industry is in the same situation. The advantages and basic quotients of each county form a pattern of county industry with their own characteristics. 


\subsection{Innovation of County Financing System}

County financing reforms are reflected in both financing and investment. While promoting enterprise reform with financing, it is necessary to focus on the technological transformation and innovation of investors to promote enterprise development.

Firstly, strengthen the function of local financing to solve the obstacles of county financing difficulties. Developing county characteristic industries under green economy, optimizing investment environment, increasing investment and attracting investment, and realizing sustainable economic strategy of combining economy with environment. And through strengthening the credit of countylevel SMEs, promoting the credit support of state-owned commercial banks, solving the problem of SME loan difficulties, and promoting the development of county economy. Secondly, in terms of investment direction and structure selection, we should focus on investment in science, technology, culture, education, health, communication and other aspects of the provincial central city and its central county to promote the development of other underdeveloped counties. Thirdly, we should strengthen traffic construction and improve the spatial relations between central cities and central cities, between central cities and sub-counties, between sub-counties and sub-counties.

\subsection{Strengthen the training of talents and enhance the county's economic and technological innovation ability}

First, improve the economic innovation capability of private enterprises in Jilin Province. We will vigorously support the county-level private enterprises to implement the brand strategy, and give priority to the technological transformation and new product opening plan policies for enterprises that have obtained national and provincial authorized brand-name products and trademarks. Second, establish a sound talent incentive mechanism. Give bonuses to scientific and technological talents who are reasonably mobile to county-level private enterprises, improve the enthusiasm of talents, and strengthen the scientific research strength of enterprises. Thirdly, we should improve the financial system to speed up the investment in talent programs and vigorously support the cultivation of innovative talents. Only by optimizing and strengthening the leading bodies of the Party and government in counties and townships to promote scientific and technological innovation and development, and at the same time increasing support for college students and postgraduates to work in counties and townships, can we further promote the strategy of "vitalizing counties through science and education" and accelerate the process of County Economic Modernization in Jilin Province.

\section{Summary}

In summary, this paper aims to promote the better development of the county economy in Jilin Province.

\section{Acknowledgment}

This paper is a social science project of the 13th Five-Year Plan of Jilin Provincial Department of Education. The title of the project is "Research on the Development Strategy of County Economic Transition in Jilin Province", and the contract number is JJKH20191321SK.

\section{References}

[1] Jilin Statistical Bureau. Jilin Statistical Yearbook 2016-2018.2016-2018.11.

[2] L. Nan. Problems and Solutions of Venture Finance for Private Enterprises in Jilin Province, Changchun Financial College Newspaper, vol. 2, pp. 20-26, 2016.

[3] L. H. Juan, L. X. Wei. Research on the development of private economy in Northeast China under the background of "one belt and one road", ECONOMIC REVIEW, vol.1, pp.24-30,2017. 